\title{
The discovery of the Fat Sand Play (Solling Formation, Triassic), Northern Dutch offshore - a case of serendipity
}

\section{J. de Jager}

Utrecht University, Faculty of Earth Sciences, P0 Box 80021, 3508 TA, Utrecht, the Netherlands.

Email: jan.dejager@hotmail.com.

Manuscript received: April 2011, accepted: July 2011

\begin{abstract}
In 1992, the well L9-7, drilled by the Nederlandse Aardolie Maatschappij (NAM) unexpectedly found a thick previously unknown sandstone interval with excellent reservoir characteristics in the Middle Buntsandstein (Triassic) of the Dutch Northern Offshore: the 'Fat Sand'. A follow-up well, L98, found this reservoir gas-bearing in an accumulation that turned out have recoverable reserves of circa 1 Tcf of gas distributed over several fault compartments. This serendipitous discovery led to a frantic period in NAM's office trying to understand the setting of this local sand development and, most importantly, assess follow-up potential; could this sand be present elsewhere in a trapping configuration? The local depocentre in which the Fat Sand accumulated is considered to be caused by local extension along a strongly listric fault soling out on the top of the Zechstein Salt. This supra-salt fault seems to be caused by early east-west extension in the Dutch northern offshore. The shape of the fault plane was strongly influenced by the presence of the nearby Zechstein Salt, and by early salt flow, which was also triggered by E-W extension.
\end{abstract}

Keywords: Exploration, Netherlands, Triassic, Solling, Fat Sand

\section{Introduction}

Drilling exploration wells is one of the most exiting activities in the oil and gas business. Not only because of the possibility to discover oil or gas, but also because seeing new well- and seismic data from an under-explored area, must come close to the thrill that once was associated with sailing through unchartered waters and discovering new lands. Apart from unveiling geology that nobody has seen before, new exploration wells always raise the question of whether our ideas and predictions of the subsurface were correct. As most seasoned explorers know, we do not always get it right; the subsurface holds unforeseen surprises. These surprises may bring disappointment when they result in a 'dry well': a well that fails to encounter hydrocarbons. Sometimes though surprises lead to new discoveries and new play concepts. Not all explorers have the luck to experience this during their career. But for those who do, it is unforgettable. Being associated with such events, even if only from the sideline, is one of the highlights in the career of an explorationist.
This happened in 1992 and 1993, when NAM drilled exploration wells L9-7 and L9-8: the seventh and eighth exploration wells in the small 20 by $20 \mathrm{~km}$ L9 block in the northern offshore of the Netherlands (Fig. 1). Well L9-7 had as objective the wellknown Lower Triassic Volpriehausen Sandstone. It was deemed a low-risk prospect because a structurally conformable amplitude at the level of the Volpriehausen reflector was interpreted to indicate that the reservoir was gas-bearing. However, the potential gas volume in the prospect was small. All in all it was not a prospect that caught the fancy of the explorers in the NAM office. Nobody was holding his breath for the results of this rather uneventful looking well. However, to everybody's surprise a hitherto unknown and astonishingly thick Triassic sandstone interval was penetrated for the first time in the Netherlands with well L9-7. And to this day it is not quite clear why this sandstone was deposited, and whether there may be more not yet identified developments of this or similar sandstones in the Southern North Sea. 


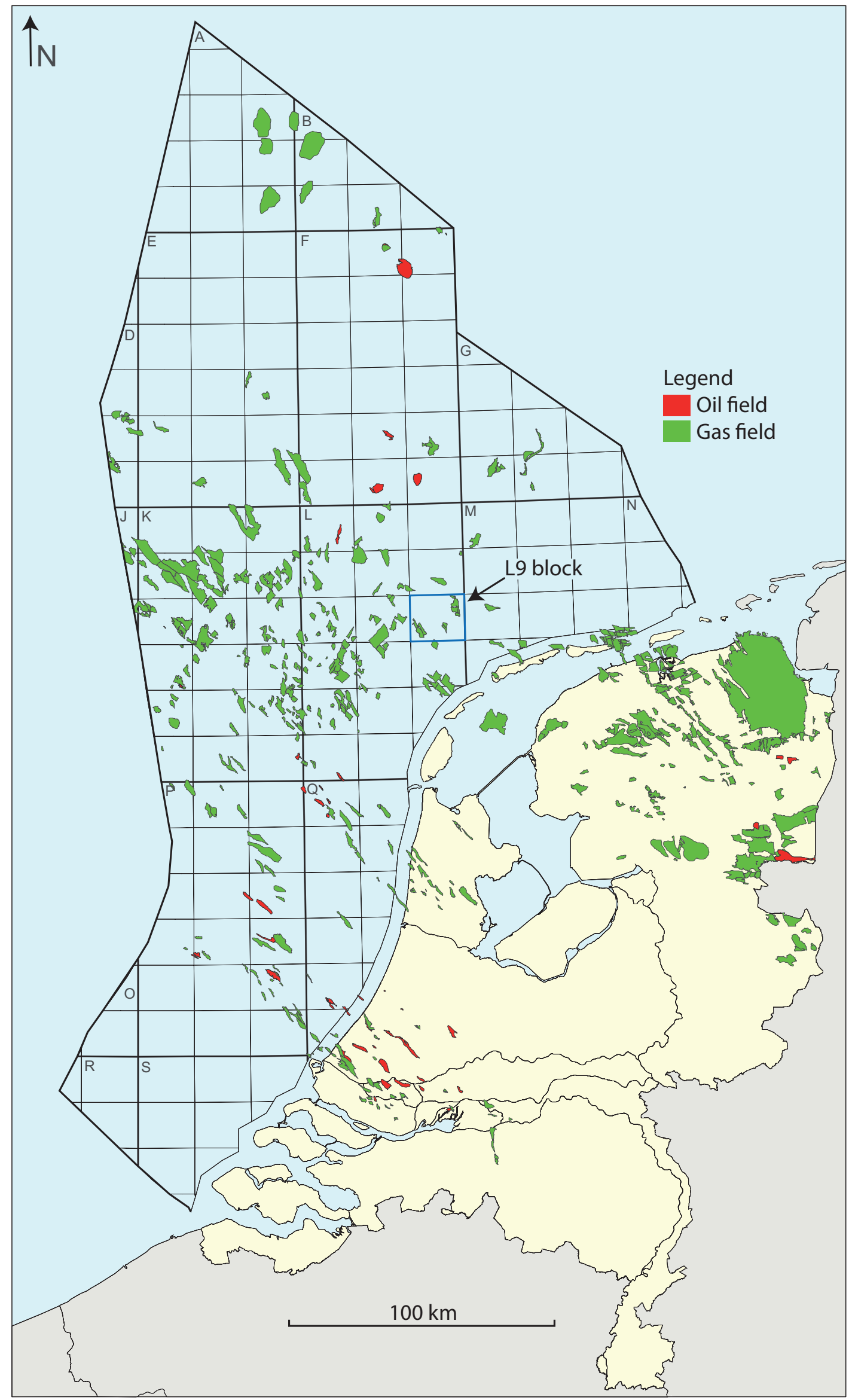

Fig. 1. Oil and gas fields in the Netherlands situation 2012 (www.nlog.nl). The L9 area is indicated with the blue box. 


\section{Geological setting}

The L9 block is located in the northern sector of the Vlieland Basin in the northern Dutch offshore (Fig. 2; De Jager, 2007; Kombrink et al., this issue). The area is underlain by a thick Carboniferous sequence of Westphalian coal-bearing strata (Van Buggenum \& Den Hartog Jager, 2007). During the Permian the block was situated in the so-called Southern Permian Basin in which the well-known sandstones of the Rotliegend were deposited, which are overlain by the thick Zechstein salt (Ziegler, 1990; Geluk, 2007a; Gast et al., 2010). The Rotliegend sandstones shale out towards the north and in most of L9 these sandstones are not present. During the Triassic and most of the Jurassic, sediments were laid down initially during continental conditions, and later in marine environments, under tectonically rather quiescent conditions, even though initial east-west extension started to affect the northern offshore, leading to thickening of sequences into the proto-Dutch Central Graben to the NW of the L9 block (Geluk, 2007b, Bachman et al., 2010). At the very end of the Jurassic and into the Early Cretaceous rifting accelerated. The present day outline of the basin was established during that period of rifting (Herngreen et al., 1991).

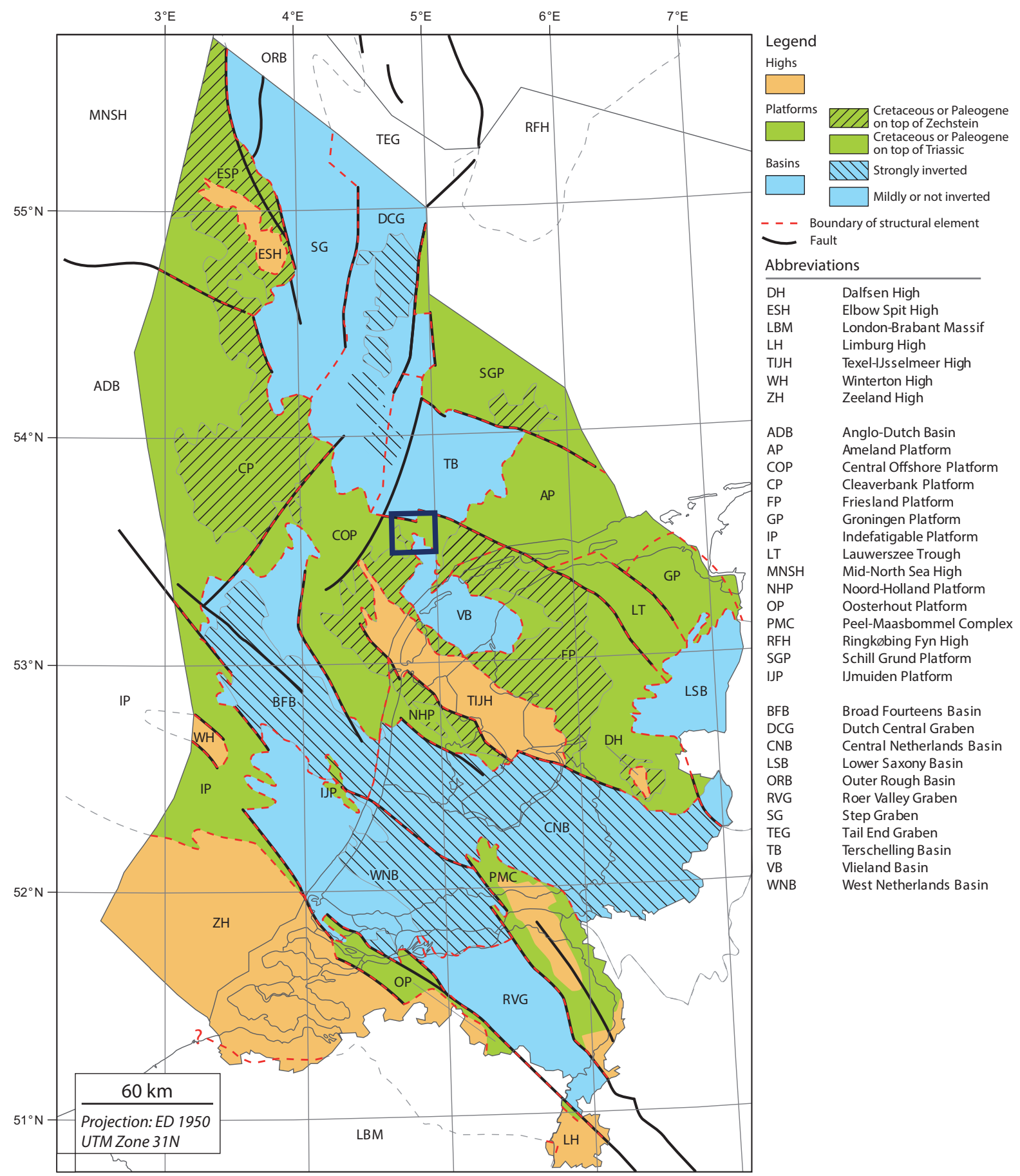

Fig. 2. Structural elements map (based on Kombrink et al., this issue). The L9 block is indicated with the blue box. 


\section{The Triassic}

In 1992, the Triassic of the Dutch offshore was well known (Fig. 3). Many wells had penetrated the Triassic succession; in the small L9 block alone there were already 6 wells that had drilled most of the Triassic. Together with many other wells in nearby blocks and a good 3D seismic coverage there was no lack of data, and our understanding of the Triassic was well documented and sound, leaving little room for surprises - or so we thought.

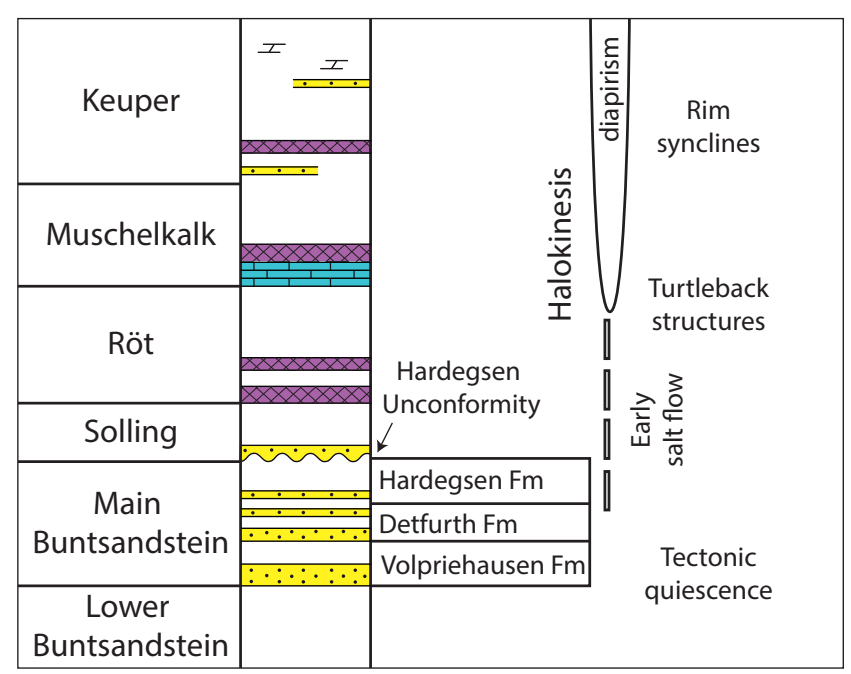

Fig. 3. Triassic stratigraphy pre-Fat Sand. The lower part of the Triassic was deposited under tectonically quiescent conditions. Towards the end of the deposition of the Buntsandstein the first effects of extension of the North Sea basin were felt, triggering halokinesis. Early salt flow led to the development of turtleback anticlines during Röt and Muschelkalk time. During deposition of the Keuper, when rifting accelerated, further halokinesis culminated in the development of piercing salt domes, flanked by rim synclines with thick Keuper deposits.
The Lower Buntsandstein Formation, deposited on top of the thick Zechstein salt, is a package of very uniform thickness, consisting mainly of claystones with minor siltstones and some thin anhydrite layers. On seismic data it has a characteristic transparent character (Fig. 4). In the Main Buntsandstein Subgroup some sand intervals occur: the Volpriehausen Sandstones of some $30 \mathrm{~m}$ thick, and the shalier Detfurth Sandstones. Thicknesses of these sandstone packages change on a regional scale only, thickening into the proto-Dutch Central Graben (Fig. 5 - not really visible here). To the north, away from the sediment source in the south, these sandstone packages gradually become thinner. The Hardegsen Formation is in the upper part of the Main Buntsandstein Subgroup and consists again mainly of claystone and siltstone, with some very thin sandstone streaks only. The upper boundary of the Main Buntsandstein is the so-called Hardegsen unconformity, resulting from gentle uplift in broad swells with most erosion over the more uplifted regions (Geluk \& Röhling, 1997). On seismic data virtually no angularity can be observed, and the unconformity can best be appreciated from regional well correlations, which show the varying truncation into the underlying sequences. The overlying Solling Fm. starts with a thin sandstone interval. The total thickness of the Solling Formation is only a few tens of metres. In the wider L9 area, intercalated sandstones have a maximum thickness of a few metres only. Overlying the Solling Formation is the Röt Formation, with thickness variations that mainly relate to the presence of the salt member in this formation.

All these Triassic units were deposited in an arid and hot continental environment, much like Central Australia today (Van der Zwan \& Spaak, 1992). The landscape was one of endless flat plains, where after very occasional rains ephemeral braided streams formed, running off to the lowest areas where temporary (salt) lakes could develop. Occasional dune fields that were
Fig. 4. Seismic section of the Dutch northern offshore showing a rather typical development of the Triassic.

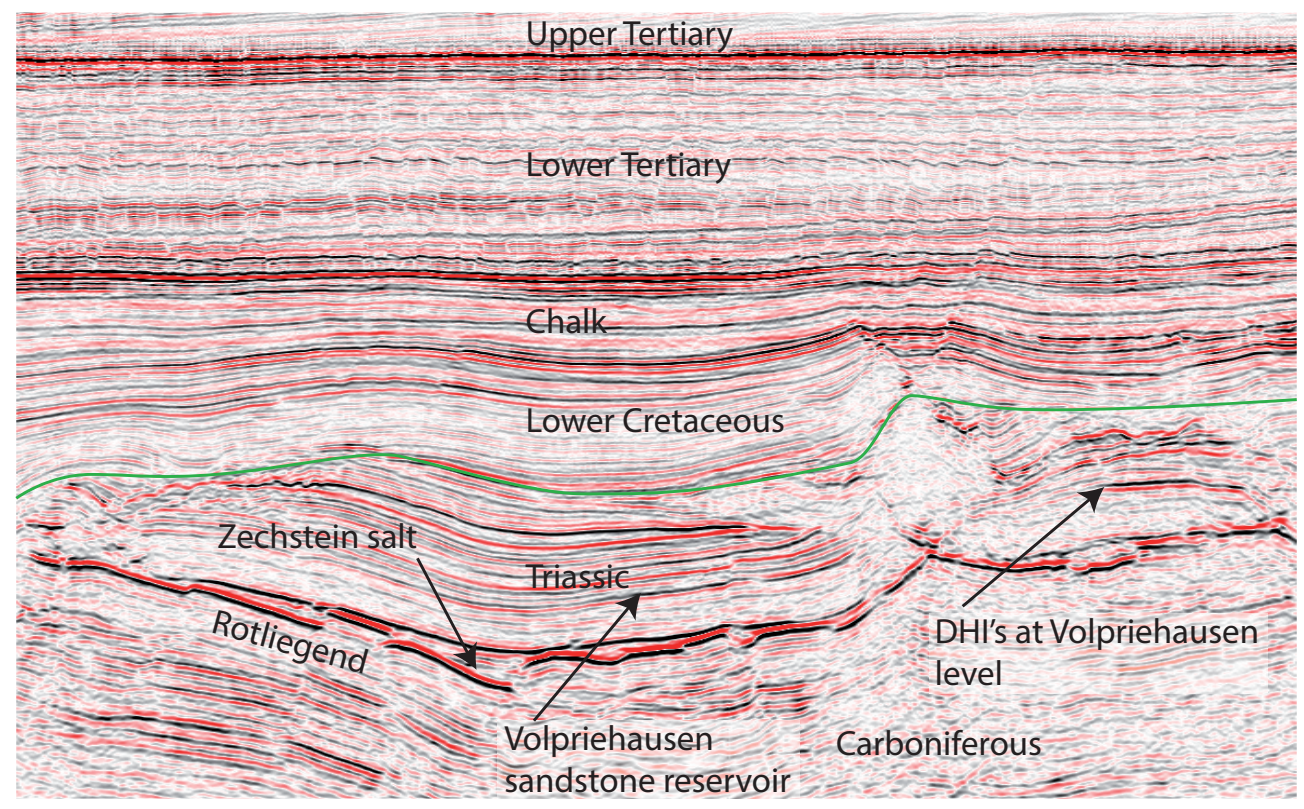




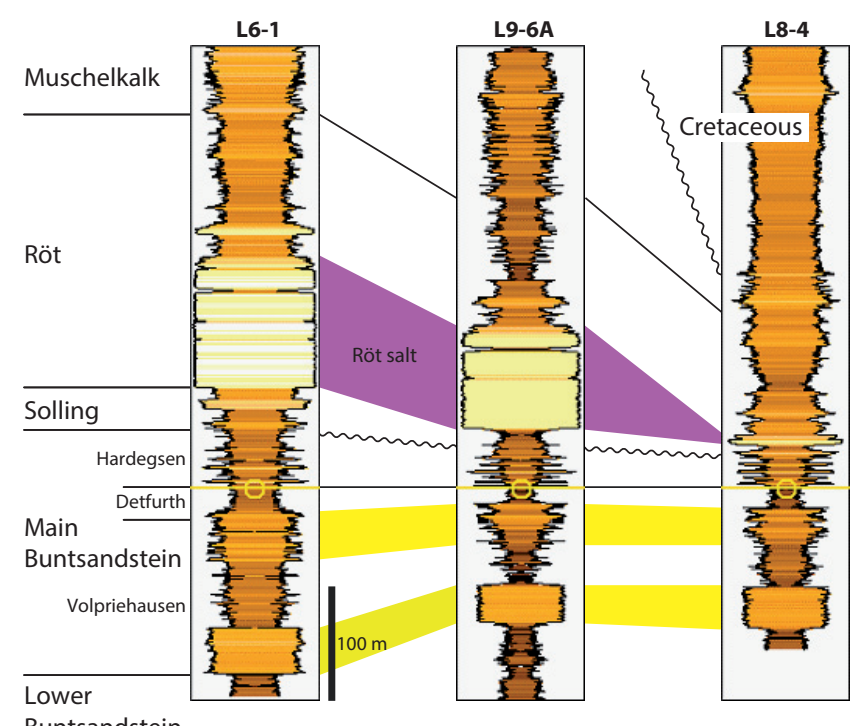

Buntsandstein

Fig. 5. Correlation panel of three wells in the area around the L9 block. Thickness variations in the Triassic below the Muschelkalk are minor only, except for the Röt Salt. The only important reservoir levels are the Volpriehausen and Detfurth sandstones.

blown across the dry plains left almost no trace; the land was much to dry for the sand to not be blown away again. Some very thin aeolian sand streaks, such as in the Hardegsen Formation, are the only remaining evidence for the fleeting existence of these dune fields. Only during the intervals of the Volpriehausen and Detfurth the supply of sand was sufficient, and the conditions were such, that thicker sand packages could be deposited and preserved.

Overlying the Röt Formation is the Muschelkalk Formation, with the first recorded fully marine conditions during Triassic times. The Muschelkalk can be seen to thicken in turtle-back anticlines, in between gentle salt swells that formed reflecting halokinetic movements of the underlying thick Zechstein salt (Fig. 6). By that time a sufficiently thick overburden of Triassic sediments had been deposited for the salt to become lighter than its overburden. The inherent instability that is associated with the light and ductile salt within the sedimentary sequence allows salt to become mobile and salt swells, and eventually domes, to develop. Extensional tectonics that had already affected areas further north, now also influenced the area close to the southern end of the Dutch central Graben and acted as triggers and venues for salt flow. Halokinesis became a very dominant factor during the deposition of the Triassic Keuper Formation. Earlier salt swells developed further into piercing salt domes and ridges. Formation of accommodation space due to halokinesis was the dominant factor controlling thickness and lithostratigraphy during the Keuper. Up to $1000 \mathrm{~m}$ of Keuper sediments were deposited in rim synclines adjacent to the salt domes and ridges, whilst over turtleback anticlines much thinner Keuper deposits accumulated, and in some areas there is no Keuper at all (Fig. 6). The great lateral variations in thickness and lithology of the accumulated sediments are a distinct feature of the Keuper. Climatic conditions were not much different from Lower and Main Buntsandstein times.

This then was the state of the knowledge and understanding of the Triassic when the well L9-7 was drilled in mid 1992. And frankly, this understanding still applies for most of the Triassic in most of the southern North Sea today (Bachmann et al., 2010; Geluk, 2007b).

\section{The Triassic Play in the Northern Offshore}

In the Dutch northern offshore, the main Triassic exploration objective is the Volpriehausen Sandstone, with the Detfurth Sandstone as secondary objective (De Jager \& Geluk, 2007; Fontaine et al., 1993; Bachmann et al., 2010). Triassic gasfields have been found in the Vlieland Basin, but also in the southern Dutch central Graben, the Terschelling Basin and on the Schill Grund High (for location of these provinces, see Fig. 2). Traps are typically related to halokinesis of the underlying Zechstein salt, and occur in turtle-back anticlines, against salt walls and in fault-controlled traps. Hard overpressures may occur in salt-enclosed settings, sometimes leading to breached seals. Although the initial reservoir quality of the Triassic sandstones can be excellent, salt plugging does occur, and is a serious risk for exploration.
Fig. 6. Schematic cross-section showing thickness relations in the Triassic of the Dutch northern offshore. In the Lower and Main Buntsandstein and Solling Fm. thicknesses tend to be very uniform over large areas. During deposition of the Röt and Muschelkalk salt flow into swells resulted into local thickening of these sequences. During deposition of the Keuper some salt swells developed further into piercing salt domes with rim synclines into which thick sequences of Keuper deposits accumulated.

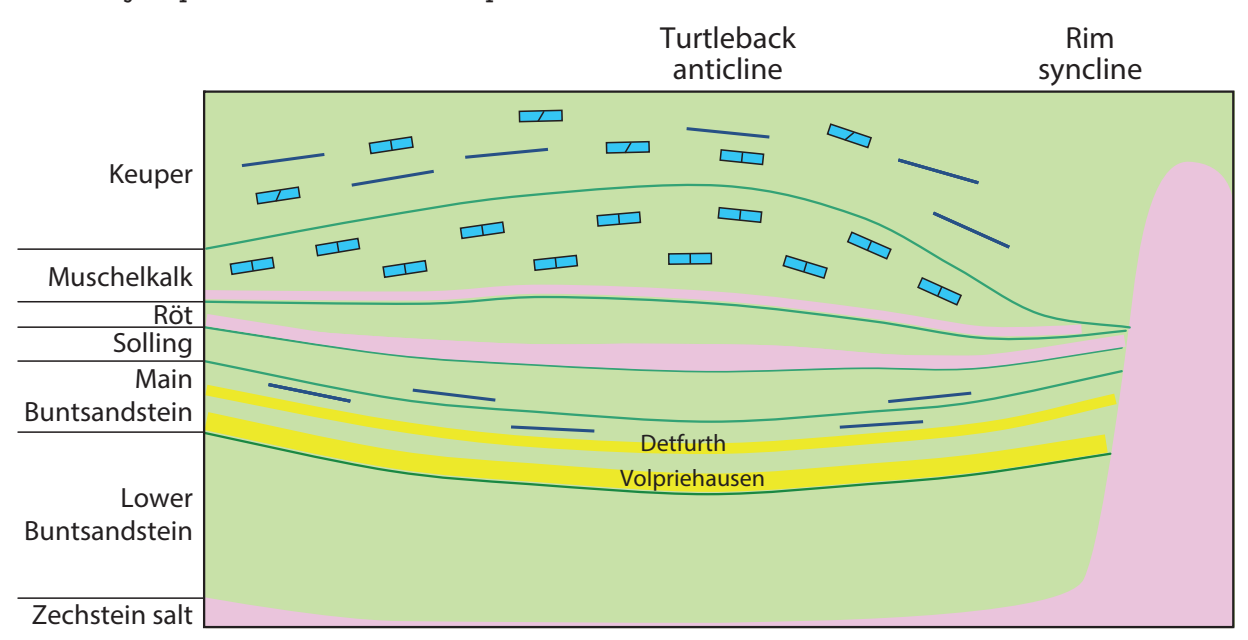




\section{The L9-7 exploration well}

The primary objective of the L9-7 well was the Volpriehausen Sandstone in a simple dip-closed trap. The drilling of the L9-7 well progressed without problems. Then, some $100 \mathrm{~m}$ above the predicted depth of the top Volpriehausen, sands appeared in the cuttings. Not just a little bit of sand: $100 \%$ sand. This caused quite some confusion in the exploration team. This surely could not be the Volpriehausen this shallow; or could it? It also was too shallow for the Detfurth. Maybe the sand came from sand stringers in the Hardegsen Formation? Several thin, and well-correlatable, sandstone streaks were known to occur in that interval. But as the well drilled on, the $100 \%$ sand interval became thicker and thicker: $20 \mathrm{~m}, 30 \mathrm{~m}, \ldots$. . Too massive for the Detfurth, it had to be the Volpriehausen. The time to depth conversion had to be seriously off; what else could it be? But with further drilling, the sand interval became even too thick for the Volpriehausen. Eventually the sand interval ended up with a thickness of $64 \mathrm{~m}$ thick along hole, and a stratigraphic thickness of $50 \mathrm{~m}$. No, this certainly was not the Volpriehausen Sandstone that we knew so well. But what was it? It immediately became clear that the reservoir characteristics of the new sand were very good. Unfortunately though, the sands were water-bearing. As the well drilled on, the Volpriehausen sandstones were found very close to their predicted depth, and gas bearing as expected. The new sand was a stratigraphically younger reservoir that we had never seen before, nor had anybody expected that such a sand could be present.

The result of well L9-7 led to an extremely exiting period in the NAM office: a new reservoir interval with exceptionally good reservoir characteristics was found. Different opinions about its age and nature caused passionate discussions. Some

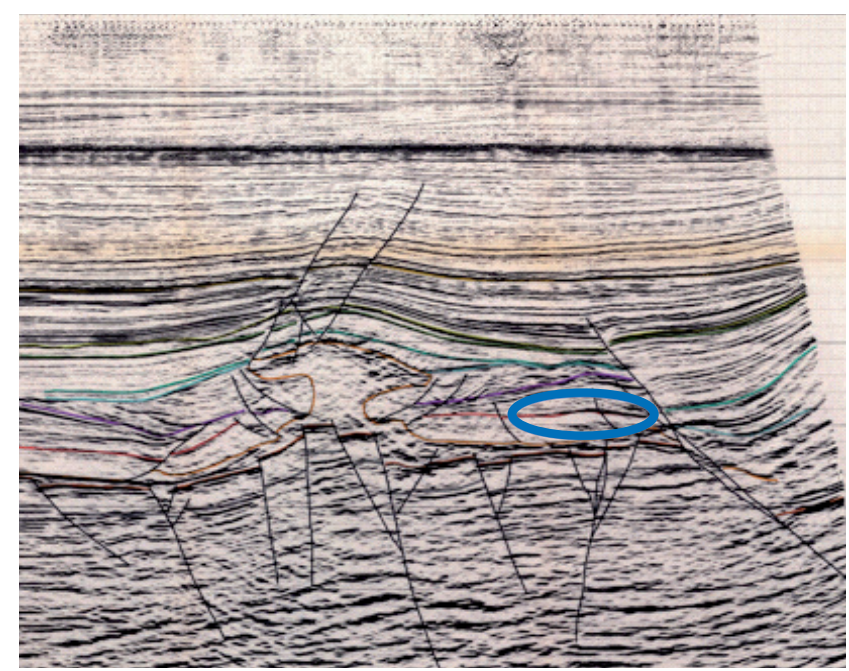

Fig. 7. Seismic section from well NAM's proposal for well L9-07 (February, 1992). The objective was the Volpriehausen Sandstone in a simple dipclosure. A structurally conform bright seismic amplitude (circled in blue) made it a low risk prospect. The well unexpectedly encountered the until then unknown and very thick Fat Sand some 100 metres above the Volpriehausen. thought that the sand had to be Keuper. After all, the Keuper was known to have the greatest variability of lithologies and thicknesses; anything seemed possible in that formation. The explorationist responsible for the L9 block (Fernando Sanchez) argued that it occurred below the Röt salt, and hence it had to be stratigraphically older. Others said that the salt interval that we had identified as Röt salt could maybe represent a Keuper salt interval. In the initial days almost everybody had an opinion, but not all of these were based on good evidence. What everybody did agree on was that the sand we found serendipitously was an exceptionally good reservoir, and that we urgently needed to understand its depositional nature and stratigraphic position better. After all, it could be gas-bearing elsewhere. Within days of its discovery the sand interval became affectionately known as the 'Fat Sand' on account of it being so massive and thick without any significant shale breaks. This informal, but very appropriate, nickname has clung to this reservoir interval until today. A formal name for the unit, Middle Solling Sandstone Member, was proposed by Geluk (2005).

\section{Follow-up drilling}

The exploration team of the area immediately tried to identify the sand on seismic data and assess its wider occurrence. Towards the east, the top Fat Sand reflector became shallower and a conspicuous increase in reflectivity updip caught the attention of Fernando Sanchez. This could be a gas effect. Further mapping revealed a valid trapping geometry, and the updip brightening seemed to occur consistently above a reasonable spill point for the trap. A well proposal to test this new prospect was written very quickly. It was a brief one; no long exposés were required to explain why this should be considered a valid prospect and one to drill urgently.

All required organisational approvals were obtained in record time, and the L9-8 well was drilled already in early 1993. It encountered the Fat Sand again, and with a stratigraphic thickness of $82 \mathrm{~m}$ it was even thicker than in L9-7. What was more, it was gas-bearing from top to bottom with, again, excellent reservoir characteristics. Later appraisal and development drilling revealed that the reservoir is locally as thick as a staggering $125 \mathrm{~m}$. The total recoverable gas volume of the discovery turned out to be 1 TCF of gas. A very good discovery indeed, and probably the best of the last 20 years of exploration in the Netherlands.

Following this exploration success, it was all hands on deck to make sure that it was understood what this sand was, how it came to be so thick, and, most importantly, where we could find it again. The well information was kept confidential, but the evaluation necessitated a large number of explorers in NAM to know everything about the well results. When in 2002 the Fat Sand play was presented at the Petroleum Geology of NW Europe Conference in London it became clear that confidentiality had been maintained, despite the large number of NAM staff that 
knew about it. The industry had understood that a significant discovery had been made in the L9 block, but had no idea of what it was. Although since then a few brief references have been made to the discovery of the Fat Sand (De Jager \& Geluk, 2007; Geluk, 2005, 2007b), this is the first more comprehensive public account of the discovery and its implications.

\section{Distribution and depositional setting of the Fat Sand}

The extensive work of a large multi-disciplinary team working in close cooperation with NAM's operational exploration team has resulted in a good knowledge of the distribution and depositional setting of the Fat Sand in the L9 block. The sand occurs below the Röt salt and above the Hardegsen, Detfurth and Volpriehausen formations of the Main Buntsandstein (Fig. 8) and is part of the Solling Formation (Fig. 9).

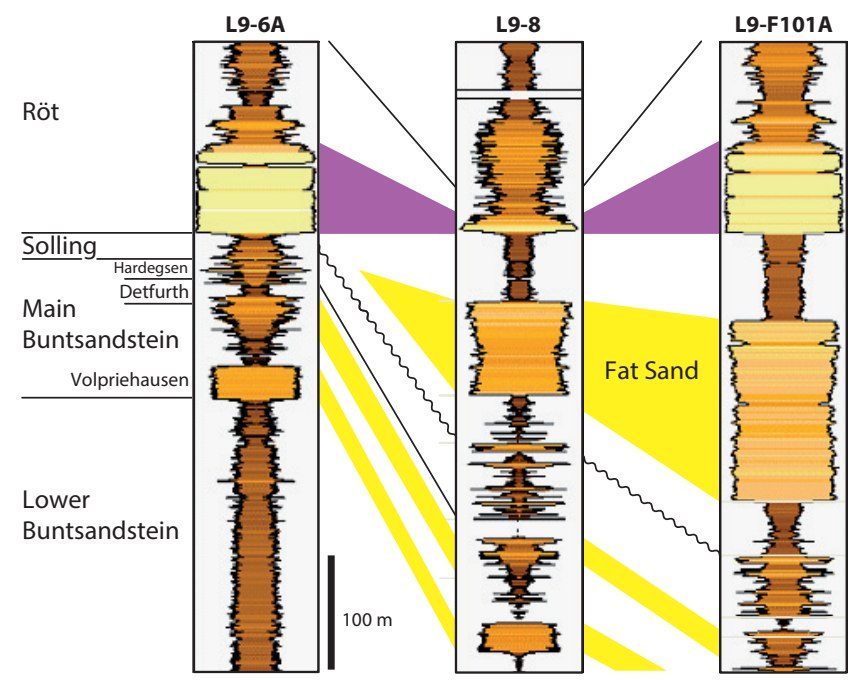

Fig. 8. Correlation panel of 3 wells in the L9 block, showing the extreme thickness variations of the Fat Sand. The Fat Sand appears as a massive clean sandstone. Its maximum measured thickness is 125 metres.

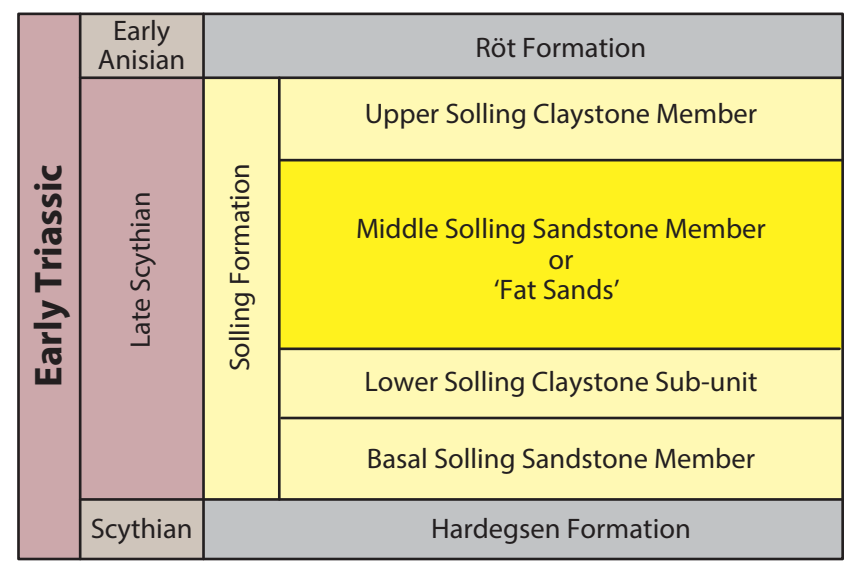

Fig. 9. The stratigraphy of the Triassic Solling Formation. What is now referred to as Middle Solling Sandstone Member, used to be referred to as Middle Solling Claystone Unit.
The Fat Sand constitutes a wedge thickening to the east, where it abuts the top of the Zechstein Salt in an apparent downlap (Figs 10 and 11). Overlying strata also clearly thicken to the east. The extent of the Fat Sand is now known to be limited the eastern sector of the L9 block and extending to the north into the southern sector of L6. There, in L6, the sand has been drilled as well, but was found to be completely saltplugged with no remaining porosity.

The entire Fat Sand interval has been cored, and the sedimentological observations clearly indicate that most of the interval is made up of aeolian sands. In wells where the sand is thickest, a thin but well-correlatable shale break in the middle of the sand package is made up of lacustrine shales.

The wedge-shaped geometry of the Fat Sand and the overlying Röt to Keuper strata indicate that in the eastern sector of L9 additional accommodation space has been created - more than in the surrounding areas - in which during deposition of the Solling Formation the Fat Sand could accumulate. It is remarkable though that away from this local depocentre virtually no trace of the Fat Sand seems to be present, although in hindsight it can be observed that in well L6-1 the sand in the middle of the Solling Formation is already a bit thicker than in other wells in the region (Fig. 5). The two main questions regarding the depositional setting of the Fat Sand are: How did this local depocentre develop? Why did such a thick package of aeolian sands accumulate in this local depocentre during Solling deposition?

\section{Development of the Fat Sand depocentre}

The wedge-shaped geometry of the Fat Sand and overlying deposits strongly resembles that of syn-tectonic deposits, thickening into a (listric) halfgraben fault. Based on this similarity and on the fact that the Fat Sand and overlying deposits appear to downlap onto the salt, the following mechanism is proposed (Fig. 12). During the later parts of the Buntsandstein deposition there is evidence for minor east-west extension in the Dutch northern offshore that resulted in an increased subsidence of the (proto) Dutch Central Graben, even though it is difficult to point to faults that were active during that time. This increased subsidence caused the Volpriehausen and Detfurth sandstones to thicken into the proto Dutch Central Graben (Geluk, 2005, 2007b). Towards the very end of Buntsandstein deposition, extensional tectonics triggered the Zechstein salt to become mobile, forming gentle swells that became more prominent later during the Triassic. The Main Buntsandstein deposition ended with regional tectonically induced uplift in broad swells. Subsequent erosion resulted in the Hardegsen unconformity. During Solling deposition eastwest extension resumed. Below the Zechstein salt this may potentially have led to a large number of minor faults, each taking up some of the distributed extension. The Zechstein salt with a thickness of many hundreds of metres acted as a very 


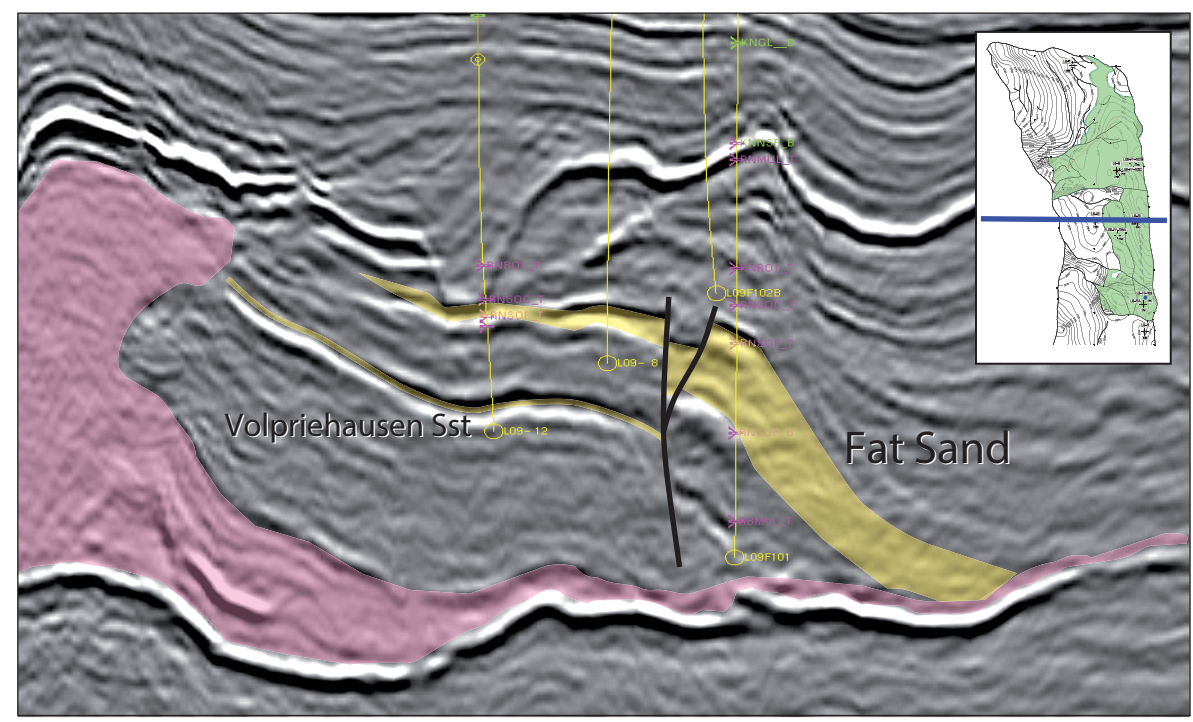

Fig. 10. With good well control the seismic profile clearly shows the geometry of the Fat Sand. The unit quickly thickens towards the west before it abuts the Zechstein Salt. The stratigraphically older Volpriehausen Sandstone (yellow line) also abuts the top of the Zechstein Salt in an apparent downlap, but which is the result of ongoing faulting along a listric fault that soles out on top Zechstein.

Fig. 11. Cartoon showing the Fat Sand geometry, based on evidence from seismic profiles. The Fat Sand and overlying Triassic units thicken to the west before abutting the top of the Zechstein Salt in an apparent downlap. Older Triassic units, including the Volpriehausen and Detfurth Sandstones also abut the top of the Zechstein Salt, but are constant in thickness.

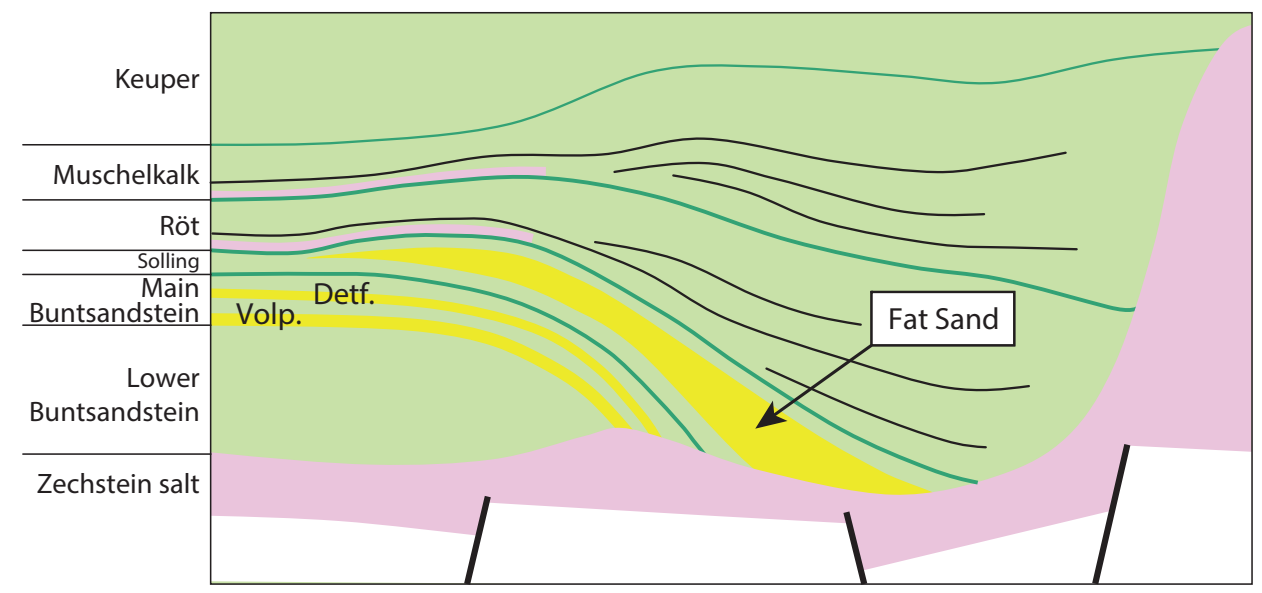

effective detachment level. It seems that above the salt the extension resulted in a much smaller number of faults, each taking up a relatively large offset. At the eastern boundary of L9 one of the most important extensional faults was active during Solling to Keuper deposition; a strongly listric fault, detaching at the top of the Zechstein salt. Because of the strong listric nature of the fault a local halfgraben developed during Solling sedimentation. Continuing extension caused the Solling lithologies, and later also overlying Röt, Muschelkalk and Keuper deposits, to thicken into the fault. With increasing extension, the syn-extensional deposits ended up in an apparent downlap onto the Zechstein salt (Fig. 12). Note this is not a depositional downlap; it is caused by long displacement along a listric fault soling out on the top of the Zechstein Salt.

In this model, the Fat Sand deposits are the first of a relatively thick sequence of syn-extensional deposits in a strongly asymmetric halfgraben. The model implies that the total extension, as can be measured along the fault plane, is very significant: in the order of several kilometres. The obvious question is whether it is realistic to assume that so much extension could occur on a single fault plane during the Triassic, i.e. during the initial phase of east-west extension. The alternative would be that the downlap of the Solling to Muschelkalk succession is in not the result of extension along a listric fault, but is in fact depositional. This is an extremely unlikely proposition. It means that the Solling Formation and younger Triassic units onlapped onto the salt, which implies that halokinesis had already progressed into a piercing saltdome reaching all the way to the surface during Solling deposition, even creating positive topography (hills). There is no evidence anywhere in the southern North Sea area that halokinesis had progressed to that stage that early in the Triassic, and it is extremely unlikely that it had in block L9. It can clearly be seen that the strata are thickening towards the 'apparent downlap'. If it were a depositional geometry, strata should be thinning towards the onlap.

Based on these considerations it is concluded that deposition in an early halfgraben with the listric fault soling out on top Zechstein salt is the most plausible explanation. It explains the observed geometries, and is consistent with an onset of extensional east-west rifting in the Dutch northern offshore towards the end of Main Buntsandstein sedimentation. The implication is that east-west extension was more significant during those times than maybe assumed by some. 


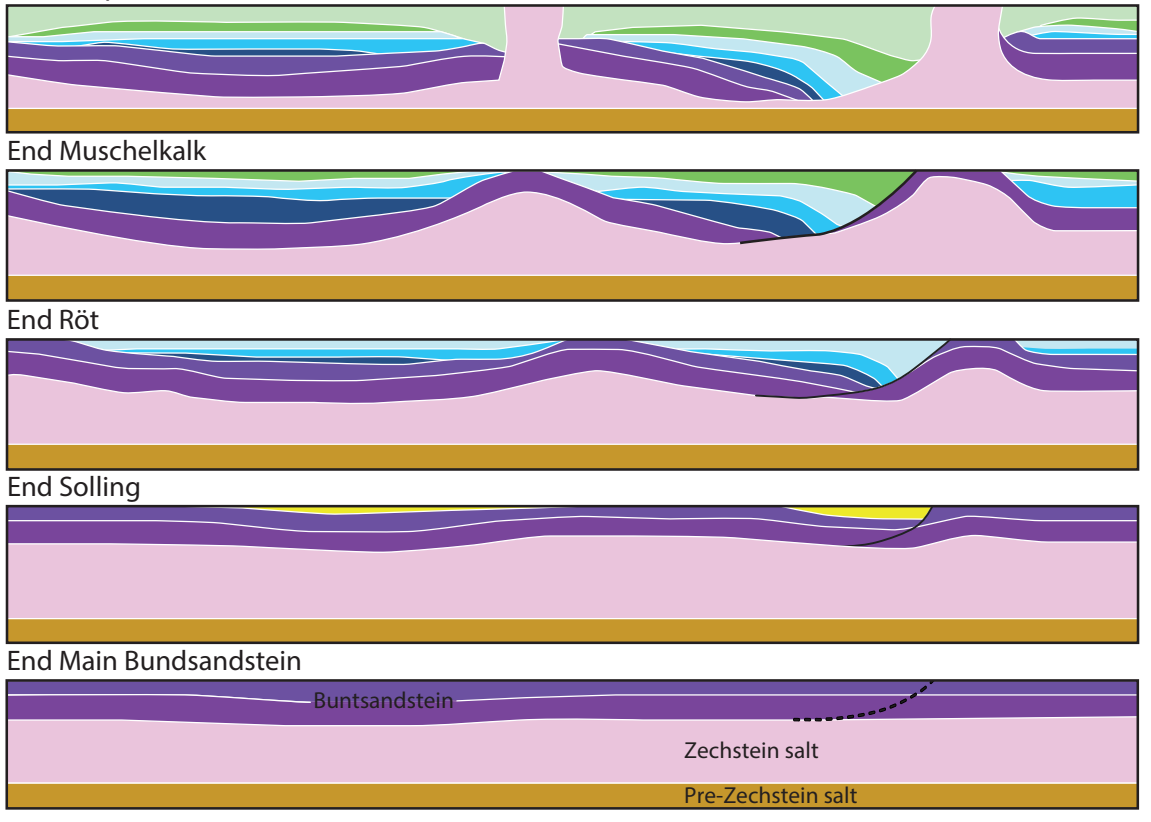

Fig. 12. Schematic palinspastic forward model to illustrate how the Fat Sand depocentre may have developed (for full explanation see text).

\section{Fat Sand depositional setting}

As indicated before, most of the sands of the massive Fat Sand sequence are of aeolian (wind-blown) origin (Fig. 13). Aeolian sands also make up significant portions of the Volpriehausen and Detfurth Sandstone intervals. Thin sandstone streaks in the Hardegsen and Solling Formations are likely to also consist for a significant part of aeolian sandstones, and of sands deposited from braided rivers. Dune fields must have been a rather common feature of the large, hot and dry Triassic plains in the Southern North Sea. Mostly, however, these dune sands would simply be blown away again. Aeolian sands have the best potential of being preserved when rising groundwater can make the sand grains stick together so that they are not so easily blown away again. The highest chance for this to occur
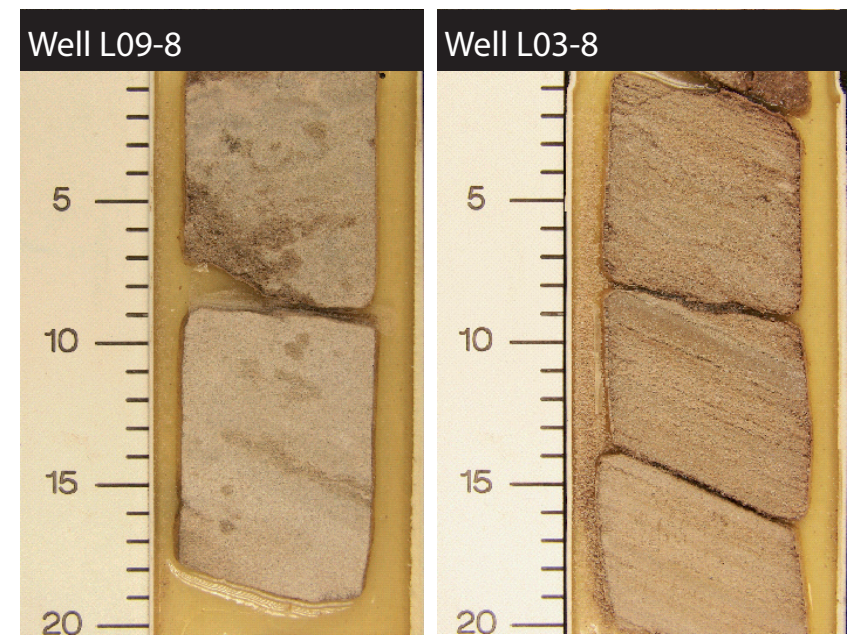

Fig. 13. In cores it can be seen that the Fat Sand is a very well sorted aeolian sandstone, often rather friable, with thinner sandstone intervals deposited by braided streams. is in places where subsidence is greater than in surrounding areas, such as in the Fat Sand halfgraben. The thin lacustrine shale interval in the middle of the Fat Sand sequence must have been deposited when the halfgraben formed a depression in the plains and when unusually strong rains turned the depression into a shallow lake.

After Solling time, the structural setting had not changed in any significant way. Röt and Muschelkalk strata can also be seen to thicken into the halfgraben in which the Fat Sand was deposited. The absence of similar aeolian sands higher in the Triassic sequence must be related to a smaller number of dune fields that were blown across the plains. This may be because the sand sources, along the basin margins, were producing less sand as continued erosion had reduced the topography. Another factor that is likely to have played an important role is that the marked increase in marine incursions, which occurred after the Solling deposition (Bachmann et al., 2010), made it problematic for dune fields to travel very large distances. The depositional environment had changed from arid inland plains to warm shallow seas and coastlands.

\section{The L9 Fat Sand field}

Much follow up appraisal and development drilling has taken place, and the Fast Sand discovery is now fully developed (Fig. 14). It is a complex of fields, with different compartments (L9-FD, L9-FF and L9-FI), overpressures, poorly consolidated sands, and locally salt plugging. Despite these problems it is one of the best producers of the southern North Sea. Gas flows on test were as high as some 2 million $\mathrm{m}^{3} / \mathrm{d}$. 


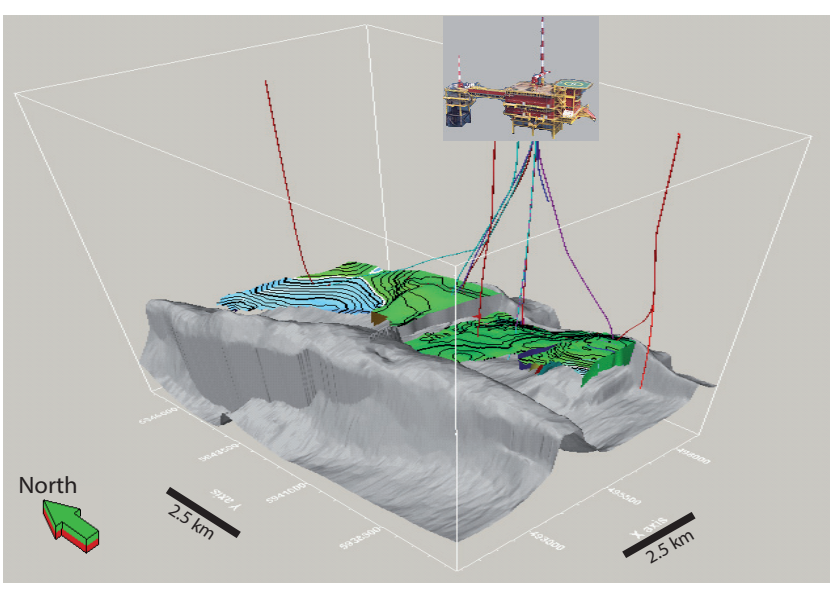

Fig. 14. The L9 Fat Sand Field Complex. Different fault compartments with different contacts and level of overpressures make up the total complex of Fat Sand fields. The extent of the gas fields is indicated in green. Where the Fat Sand occurs below the GWC and is water-filled, it is indicated in light blue.

\section{Follow-up potential of the Fat Sand discovery}

The Fat Sand discovery in block L9 proves that at least one local depocentre developed during Solling deposition in the southern North Sea in which a thick package of exceptionally good aeolian reservoir sands were deposited. It seems to be too much of a coincidence to think that we 'stumbled over' the only one of these depocentres, and it is tempting to assume that more similar depocentres must be present, waiting to be discovered. Unfortunately though, a concerted effort by NAM to find additional Fat Sand occurrences has not lead to exploration success. In L6, the northward continuation of the L9 Fat Sand depocentre has been encountered, but the thick sands are pervasively salt-plugged. Onshore the Netherlands, to the southeast of the Groningen Field, geometries were recognised in the Lower Triassic that resemble those of the L9 Fat Sand setting. A prospect was mapped and the Jipsinghuizen well was drilled in 1997. The well encountered a good Solling reservoir interval, but no gas. It was concluded that the seal was breached. In Jipsinghuizen-1 the reservoir is not as well developed as in L9, but it was very encouraging indeed to find that based on the understanding of the geological setting and depositional geometries the presence of a local development of good Solling sandstones was correctly predicted. Although in some locations geometries can be observed that also are reminiscent of the Fat Sand setting, no potential traps have been mapped at these locations. Without additional prospects, no additional wells have been drilled with the objective to test a potential new Fat Sand occurrence.

\section{Epilogue}

The Fat Sand discovery in block L9 of the Dutch northern offshore demonstrates that even in a mature exploration setting as the Netherlands one should be prepared for surprises. Explorers tend to have a rather optimistic view on what may be found in the subsurface, and consequently, unsuccesful well outcomes tend to bring disappointment. In the case of the L9-7 and L9-8 wells, however, the unexpected well result led to exploration success: a hitherto unknown reservoir interval with exceptional reservoir characteristics appeared gas bearing with initial reserves of circa $1 \mathrm{TCF}$ of gas. If pre-drill the possibility of encountering a new reservoir interval up to more than $100 \mathrm{~m}$ thick with 1 TCF of recoverable gas reserves would have been suggested, this would have been dismissed as wishful thinking. Probably also if the exact reservoir model would have been presented in support of such a prediction.

The Fat Sand discovery is thus a forceful reminder of how little we actually know of the subsurface details, despite all the wells and 3D seismic data to calibrate our models. We, explorers, tend to assume that we understand the subsurface much better than we actually do. This realisation entices some explorers to often present overly favourable scenarios for the outcome of their prospects; after all, 'you never know'. The Fat Sand story supports that indeed unlikely scenarios may materialise. Nevertheless, it must be stressed that an overly optimistic approach tends to lead to irresponsible business decisions and disappointment where good money is wasted on bad exploration prospects. Rather than being unrealistically optimistic, explorers should strive to be creative. Explorers should always endeavour to have a very open mind of what they may encounter in new wells. Different scenarios can, and in many cases should, be considered. This is not always self evident; the natural inclination is to concentrate on a single 'hoped for' subsurface scenario only. It takes discipline and effort to consciously consider alternatives and their implications and to estimate their chance of occurring (scenario weighting). Such alternative scenarios can range from very favourable to unfavourable. These scenarios may have been conceived through out-of-thebox thinking with little scientific constraints. The important point is that once they are on the table, we must use sound and unbiased science-based geological arguments to assign realistic scenario weights. This will ensure that our exploration wells do not raise inflated expectations and that we can make responsible business decisions, while still being prepared for the unexpected.

Finally, the romance of exploration is just because of the inherent uncertainties associated with drilling exploration wells. Our geological models and predictions are always based on sparse, incomplete and often uncertain data. We apply our knowledge, understanding and technology to reduce subsurface uncertainties as best we can. When a well comes in as predicted, we feel great because of a job well done. But the greatest thrill 
in exploration is the positive surprise of finding a new play such as the Fat Sand play.

It is difficult to accept that there would be no other unexpected significant gas or oil accumulations hiding in our subsurface. If we want to find another one, we need creative explorers who can come up with models and interpretations that have not been proposed before, but are consistent with all available subsurface data. And we will have to accept that this may not be enough, after all we tend to know less of the subsurface than we think. Maybe we need to give serendipity a chance by being brave enough to every now and then drill exploration wells in areas and through sequences that we do not image or understand very well. If we do so, maybe luck strikes again.

\section{Acknowledgements}

This article is published by permission of the Nederlandse Aardolie Maatschappij BV (NAM), Shell Internationale Petroleum Maatschappij BV and ExxonMobil. The geological concepts presented have been developed by a team of many NAM colleagues, whose contributions are hereby gratefully acknowledged. The author is indebted in particular to Fernando Sanchez; the author of the well proposals that led to the discovery of the Fat Sand. Constructive comments by Mark Geluk and Gerhard Bachmann are highly appreciated and have improved of the manuscript.

\section{References}

Bachmann, G.H., Geluk, M.C., Warrington, G., Becker-Roman, A., Beutler, G., Hagdorn, H., Hounslow, M.W., Nitsch, E., Röhling, H.-G., Simon, T. \& Szulc, A., 2010. Triassic. In: Doornenbal, J.C. \& Stevenson, A.G. (eds): Petroleum Geological Atlas of the Southern Permian Basin Area. EAGE Publications b.v. (Houten): 149-173.

De Jager, J., 2007. Geological development. In: Wong, T.E., Batjes, D.A.J. \& De Jager, J. (eds): Geology of the Netherlands. Royal Netherlands Academy of Arts and Sciences (KNAW) (Amsterdam): 5-26.

De Jager, J. \& Geluk, M.C., 2007. Petroleum geology. In: Wong, T.E., Batjes, D.A.J. \& De Jager, J. (eds): Geology of the Netherlands. Royal Netherlands Academy of Arts and Sciences (KNAW) (Amsterdam): 241-264.

Fontaine, J.M., Guastella, G., Jouault, P. \& De la Vega, P., 1993. F15-A: a Triassic gas field on the easetrn limit of the Dutch Central Graben. In: Parker, J.R. (ed.): Petroleum Geology of North-West Europe: Proceedings of the $4^{\text {th }}$ Conference. The Geological Society (London): 583-593.

Gast, R.E., Dusar, M., Breitkreuz, C., Gaupp, R., Schneider, J.W., Stemmerik, L., Geluk, M.C., Geißler, M., Kiersnowski, H., Glennie, K.W., Kabel, S. \& Jones, N.S., 2010. Rotliegend. In: Doornenbal, J.C. \& Stevenson, A.G. (eds): Petroleum Geological Atlas of the Southern Permian Basin Area. EAGE Publications b.v. (Houten): 101-121.
Geluk, M.C., 2005. Stratigraphy and tectonics of Permo-Triassic basins in the Netherlands and surrounding areas. PhD thesis, Utrecht University (Utrecht), $171 \mathrm{pp}$.

Geluk, M.C., 2007a. Permian. In: Wong, T.E., Batjes, D.A.J. \& De Jager, J. (eds): Geology of the Netherlands. Royal Netherlands Academy of Arts and Sciences (KNAW) (Amsterdam): 63-84.

Geluk, M.C., 2007b. Triassic. In: Wong, T.E., Batjes, D.A.J. \& De Jager, J. (eds): Geology of the Netherlands. Royal Netherlands Academy of Arts and Sciences (KNAW) (Amsterdam): 85-106.

Geluk, M.C. \& Röhling, H.G., 1997. High-resolution sequence stratigraphy of the Lower Triassic Buntsandstein in the Netherlands and northwestern Germany. Geologie en Mijnbouw 76: 227-246.

Herngreen, G.F.W., Smit, R. \& Wong, T.E., 1991. Stratigraphy and tectonics of the Vlieland basin, the Netherlands. In: Spencer, A.M. (ed.): Generation, accumulation and production of Europe's hydrocarbons. Special Publication of the European Association of Petroleum Geoscientists (Berlin): 175-192.

Kombrink, H., Doornenbal, J.C., Duin, E.J.T., Den Dulk, M., Van Gessel, S.F., Ten Veen, J.H. \& Witmans, N., 2012. New insights into the geological structure of the Netherlands; results of a detailed mapping project. Netherlands Journal of Geosciences 91-4: 419-446, this issue.

Van Buggenum, J.M. \& Den Hartog Jager, D.G., 2007. Silesian. In: Wong, T.E., Batjes, D.A.J. \& De Jager, J. (eds): Geology of the Netherlands. Royal Netherlands Academy of Arts and Sciences (KNAW) (Amsterdam): 43-62.

Van der Zwan, C.J. \& Spaak, P., 1992. Lower to Middle Triassic sequence stratigraphy and climatology of the Netherlands, a model. Palaeogeography, Palaeoclimatology, Palaeoecology 91: 277-290.

Ziegler, P.A., 1990. Tectonic and palaeogeogaphic development of the North Sea Rift system. In: Blundell, D.J. \& Gibbs, A.D. (eds): Tectonic Evolution of the North Sea Rifts. Oxford Science Publications (0xford): 1-36. 